\title{
Belgeo
}

Revue belge de géographie

$1 \mid 2021$

Miscellaneous

\section{The Euro-Mediterranean region: human mobility and sustainable development}

La région euro-méditerranéenne: mobilité des personnes et développement durable

\section{Armando Montanari}

\section{OpenEdition}

\section{Journals}

Electronic version

URL: https://journals.openedition.org/belgeo/49993

DOI: 10.4000/belgeo.49993

ISSN: 2294-9135

Publisher:

National Committee of Geography of Belgium, Société Royale Belge de Géographie

Electronic reference

Armando Montanari, "The Euro-Mediterranean region: human mobility and sustainable development", Belgeo [Online], 1 | 2021, Online since 11 August 2021, connection on 24 October 2021. URL: http:// journals.openedition.org/belgeo/49993 ; DOl: https://doi.org/10.4000/belgeo.49993

This text was automatically generated on 24 October 2021.

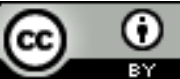

Belgeo est mis à disposition selon les termes de la licence Creative Commons Attribution 4.0 International. 


\title{
The Euro-Mediterranean region: human mobility and sustainable development
}

\author{
La région euro-méditerranéenne : mobilité des personnes et développement \\ durable
}

Armando Montanari

\section{Introduction}

1 For at least thirty years now, the social sciences have viewed the concept of human mobility as a consequence of the processes of globalisation and economic internationalisation. Whenever we have to face the consequences of a crisis - be it economic, social, or even a pandemic - innovative processes need to be put in place to overcome it. Among the many innovations that have been introduced in past decades as a result of geopolitical or economic crises, we might mention here the new ways of acting following changes to production, economic processes and financial flows. In the 1980 s and 1990s independent migration flows began to develop, no longer stimulated by bilateral governmental agreements but rather a continuation of previous migration flows. The geographic features of the Mediterranean area have favoured movements from countries in the South to those in the North. Up until the 1980s the citizens of countries such as Portugal, Spain, Italy and Greece had been emigrating to France, the UK and Germany. Then, without people always realising, the same countries began to attract emigrants (Montanari, Cortese, 1993). At the same time, tourist flows from continental Europe were on the rise, spending holiday periods on the northern shores of the Mediterranean (Marchena Gómez, Vera Rebollo, 1995). Tourism-related economic development required new labour flows, supplemented by the migration of retirees from northern and central Europe to the shores of the Mediterranean (Tomás Salvá, 2002). Based on this empirical evidence - there was no longer a push-pull relationship, but rather a network-based horizontal distribution - a new theory of 
human mobility was developed, considering the various components of integrated flows from both a consumption and production point of view. This essay examines the theme of human mobility in the Mediterranean area in relation to economic and social change and to the impact that these trends might have on the natural and cultural environment. We therefore refer to the impact of mass tourism on the natural environment, in particular coastal areas, and on the manmade environment, such as the numerous historical cities. The problem of urban and coastal overtourism exists only in the northern zones of the Mediterranean region. The numerous geopolitical problems that continue to affect the region mean that the southern shores are in a state of constant instability, preventing lasting development. Similarly, it will be difficult to solve the problem of illegal migration without solving the problems of population growth and unemployment, which have fuelled the phenomenon in recent decades. The management of the environment and of cultural resources can also be effective only in a climate of North-South collaboration. It appears unlikely that the principles of sustainability can be applied in the southern Mediterranean region without adequately managing the economic, social and political problems affecting these countries. The management of all these problems requires collaboration between EU countries and other non-EU Mediterranean countries in order to foster a process of environmental, economic and social sustainability. The consequences of the Covid-19 pandemic have slowed down human mobility flows and made North-South relations more complicated.

\section{From the Euro-Mediterranean Region to the Union for the Mediterranean}

2 The Euro-Mediterranean cooperation area has been constructed in a number of stages in response to the international situation and the changes that have taken place within what we now call the EU. According to Isaac and Kares (2017), from 1970 to 1990 the policies of European countries in respect of countries in the Mediterranean region evolved over time. An initial phase was dominated by Cold War issues, thus limited to economic agreements within a broader strategy of military influence. The first enlargement of the EU (01/01/1973) shifted the centre of gravity of geopolitical interests northwards. The second and third EU enlargements in the 1980s came after the fall of dictatorial regimes in Portugal, Spain and Greece, thus the problems of the Mediterranean became more pressing (Tsoukalis, 1977). The European Parliament resolution of 1973 first mentioned a Global Mediterranean Policy (GMP), even though the term Global was limited to 17 Mediterranean countries. Euro-Mediterranean relations saw highs and lows with the energy and economic crises of the 1970s and the consequent opportunity for greater cooperation with oil-producing Arab countries. The 1990s are considered to be the beginning of the phase that led to the definition of what is now called the Euro-Mediterranean region. This phase was marked by a far-reaching debate both internationally and within individual countries. Morillas and Soler i Lecha (2017) listed 227 published essays that sought to identify the various aspects and numerous consequences of this new policy. The Euro-Mediterranean Partnership was established with the Barcelona Declaration (28/11/1995), adopted at the conclusion of the Conference of Foreign Ministers of the Euro-Mediterranean region. The conference was attended by the $27 \mathrm{EU}$ member States and 12 non-EU Mediterranean countries, all 
coastal nations except for Libya. The Cannes European Council in June 1995 decided to allocate much more budgetary resources to the partnership than had previously been the case. All this additional funding was managed through the MEDA programme, the principal financial instrument of the EU for the implementation of the EuroMediterranean Partnership. The basic goal of economic, political and social restructuring of the Euro-Mediterranean region, following the implementation of the MEDA programme, was to reduce North-South imbalances and liberalise trade, tourism and migration flows. It was believed that flows of goods and people, interacting with other economic, environmental and social variables, would help to reduce the economic and social differences between the EU and Mediterranean countries. These were identified according to three types of objectives: (a) the actual reduction of NorthSouth imbalances, (b) the restructuring of the region, without unduly affecting the peculiar traits of cultural and natural environments, (c) the absorption by civil society of the effects of restructuring without unduly affecting lifestyles, customs, cultural traits, ethical and religious values and the role of the family. Events unfolded around the turn of the century, such as the Arab-Israeli conflict and the attack of 11 September 2001, that enforced a mainly geopolitical vision of the Euro-Mediterranean Region (Morillas, Soler i Lecha, 2017). According to Cebeci and Schumacher (2017), discussion on the Mediterranean has shifted from a normative and transformative approach to one of pragmatism, seeking solutions to specific problems. In the meantime, priorities had been identified, namely to manage illegal migration and border security, and to deal with the dangers posed by terrorism. Right from the outset, France has played a key role in promoting Euro-Mediterranean policy, in order to both reaffirm its role in the region and to manage the caution, and sometimes reluctance, of countries in northern and central Europe. Speaking as President of the European Commission in favour of the establishment of a Euro-Mediterranean Foundation, Romano Prodi (2004) pointed to the shortage of minimum funding requirements: member States were unwilling to come up with $€ 5$ million to add to the $€ 5$ million provided by the European Commission. During the electoral campaign for the presidency of the French Republic M. Sarkozy (2007) gave a speech in Toulon, a Mediterranean city, in which he reaffirmed that the culture and history of the Mediterranean played a large part in the make-up and identity of all Europeans. This premise was made to urge Mediterranean countries in the EU to form a Mediterranean Union modelled along the lines of the EU, in order to facilitate the creation of common institutions. The priorities of the Union for the Mediterranean were to have been migration management and environmental protection. The third priority is co-development, with laboratories and universities working in unison rather than in competition. The fourth priority is integrated cooperation to combat corruption, organised crime and terrorism, supported by a common judicial area. The Union for the Mediterranean was established at a summit held in Paris (13/07/2008) at the initiative of M. Sarkozy, President of the French Republic. It was set up as an intergovernmental organisation comprising the 27 countries of the EU and 15 non-EU Mediterranean countries, 4 in Europe, 4 in Africa, 7 in the Middle East. Migration, terrorism, the Israeli-Palestinian conflict and the natural environment were identified as priority objectives. During the Summit with countries in the south of the EU, the President of the French Republic, M. Macron (2021) spoke about the questions of Mediterranean peace, migration and relations with Turkey. He also announced the organisation of a Summit in Marseilles in 2021 to discuss cooperation between the two sides of the Mediterranean in the fields of energy, 
biodiversity, climate change, health, education, training, university, culture and heritage. Borrell (2021) confirmed the crucial importance of Mediterranean cooperation for EU countries, since challenges faced together have a greater chance of turning into opportunities. He then announced a new neighbourhood, development and international cooperation instrument, which would be endowed with $€ 7$ billion funding for the period 2021-27 and could mobilise public and private investments to the tune of $€ 30$ billion over the next ten years. In reporting to the European Council about the Euro-Mediterranean partnership, the European Commission (2021) dealt with the topics of the Arab Spring and the frustrated hopes of young people who emigrate due to a lack of freedom, lack of jobs and lack of hope for the future; demographic trends and economic crises, preventing well-trained youngsters from entering the workplace; renewable energy; greater economic cooperation between the EU and Mediterranean countries; the need for the greater involvement of EU countries in Mediterranean policy.

\section{Human mobility}

3 The concept of human mobility has been studied for over two decades to help explain some of the causes behind and consequences of processes of globalisation and economic internationalisation. "Hard mobility", signifying the physical movement of people and goods, but also of pathogens and pandemics, is the cause and the consequence of forms of "soft mobility", which refer to the transmission of culture, information, lifestyles and financial flows. Up until the years of postmodern society, these phenomena were deemed to be apparently independent, and in any case identifiable and quantifiable, with often artificial rules useful for defining at international level their size and characteristics (Montanari, 2002). In contemporary postmodern society, with the internationalisation of the economy and globalisation of phenomena, material and immaterial flows have overlapped, making it difficult to identify them unambiguously (Montanari, Staniscia, 2016). Researchers in this field have separated flows based on two fundamental principles: a) flows serving to produce: economic migration, and b) flows serving to consume: recreation and tourism (Hall, Williams, 2002). The work of Urry (2000) is an important point of reference for research in this field and a stimulus for the establishment of the GLOBILITY research network ${ }^{1}$. The unrestricted movement of information and communication has been placed at the heart of contemporary society, based on the fluidity of relations. Agreements have been reached for the exchange of goods at a global level. This has not been the case however regarding the free movement of persons. The movement of persons for consumption-based reasons, traditionally referred to as tourism, does not appear to cause any problem, however: the greater the flows the greater the benefits (often only apparent) for the countries receiving such flows. Acknowledging that consumer-based mobility may overlap with production-based mobility can lead to cultural and ideological problems. It has been clear for many years that the presence of an excessive number of tourists in coastal regions (Montanari, Magnarapa, 1998) and in historical cities on the northern shores of the Mediterranean is creating serious problems with regard to the management of the natural and cultural environments. This phenomenon has been given the name "overtourism" (Montanari, 2020). In the new millennium these flows have become magma-like: their direction is not easy to predict or justify, motivations are apparently irrational. This process was initially homogeneous and to 
an extent predictable at a global level, but has now taken on diverse and specific traits at a local level. Thus global and local trends are not contrasting, but form part of the same system, in which the local level attempts to hold onto an effective dialectical position. We refer to liquid sociology, which acts to contrast networks and form a heterogeneous, uneven and unpredictable mobility.

\section{The Mediterranean region}

The Euro-Mediterranean region includes all EU and non-EU countries looking onto the Mediterranean Sea. The actual Mediterranean area is that comprising countries looking directly onto the Mediterranean, on both the southern and northern shores. This area has a precise geographical and historical significance, being a hub of cultural, social and economic exchanges that have developed over the millennia. The Mediterranean region thus defined no longer exists as a geopolitical dimension, as it now constitutes a common area for both countries looking onto the Mediterranean and all other EU countries. It is in this macro area that most human mobility flows (tourism and migration), cultural exchanges, international trade and economic transitions now occur. It is a pole of attraction for all Europeans thanks to its rich and varied historical and environmental features, with three continents - Europe, Africa and Asia - having coastlines looking onto this Sea.

Figure 1. The definition of Mediterranean based on bioclimatic boundaries.

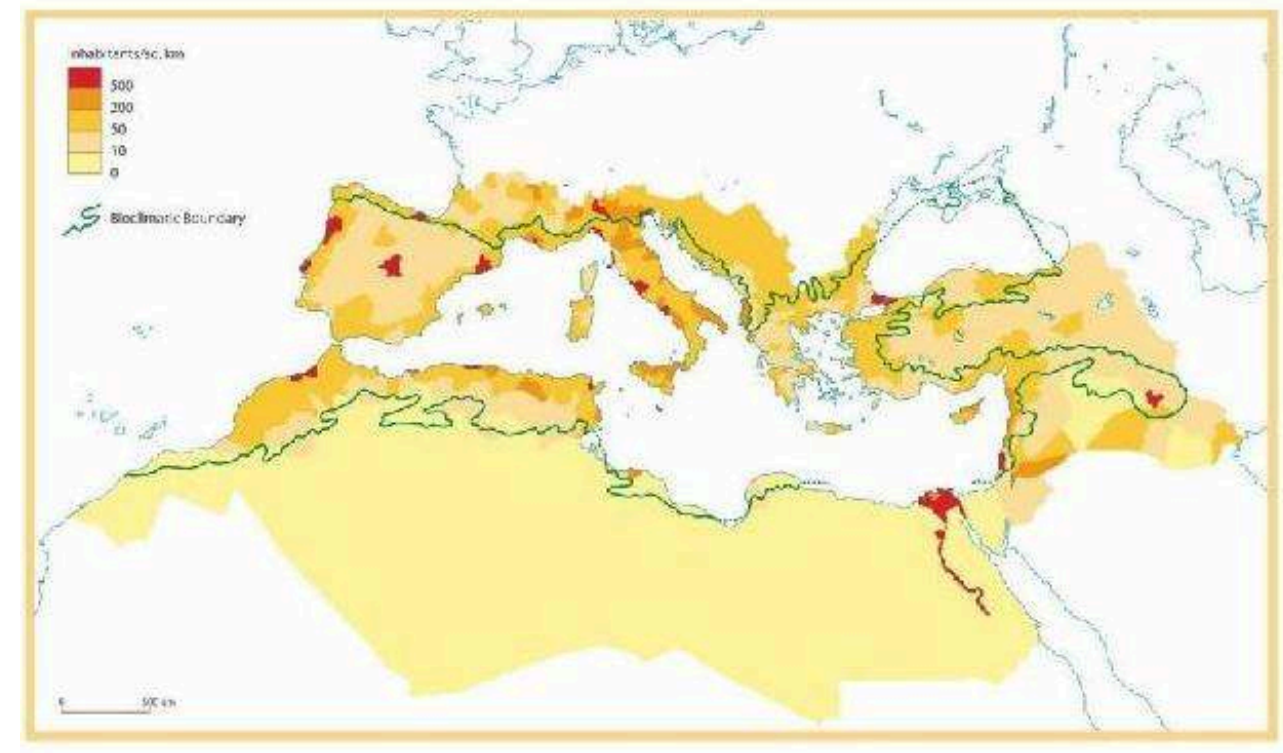

In previous studies on the Region (Montanari, 1995) it had been necessary to move beyond the traditional geographical dimension and the presumed inclusion of all parts of countries looking onto the Mediterranean, focusing on other more significant elements capable of illustrating the peculiar traits of the area. These elements include bioclimatic factors, such as hot and dry summers and a rainy period arriving mainly in the autumn and winter months, thanks to the effect of sea currents. The bioclimatic boundary (fig. 1) determines the presence of typical vegetation, landscapes and diets. This boundary also indicates limitations on the presence of olive trees, the 
Mediterranean plant par excellence, essential for the food consumption model commonly referred to as the Mediterranean diet. For these reasons, only those provinces in France and Turkey that look directly onto the Mediterranean Sea have been defined as Mediterranean. For the same reasons, those countries and regions that have environmental, historical and cultural characteristics typical of the Mediterranean, even if they are not geographically a part of the region, such as Portugal, western areas of Morocco and part of Iraq, have been included. Iraq, although geographically far from the Mediterranean coasts, is part of the Mediterranean for history, culture, religion, and finally for the vegetal species that originated from the Fertile Crescent and now characterize the Mediterranean landscape. In the Mediterranean thus defined, there are small but dense urban areas, formed over the course of the centuries, that have been the scene of major historical events and seen the emergence of civilizations that have developed in the area and left us the historical, artistic, architectural and archaeological reminders of what we can call the Mediterranean culture.

Figure 2. Traces of history, major civilizations and their geographic expansion.

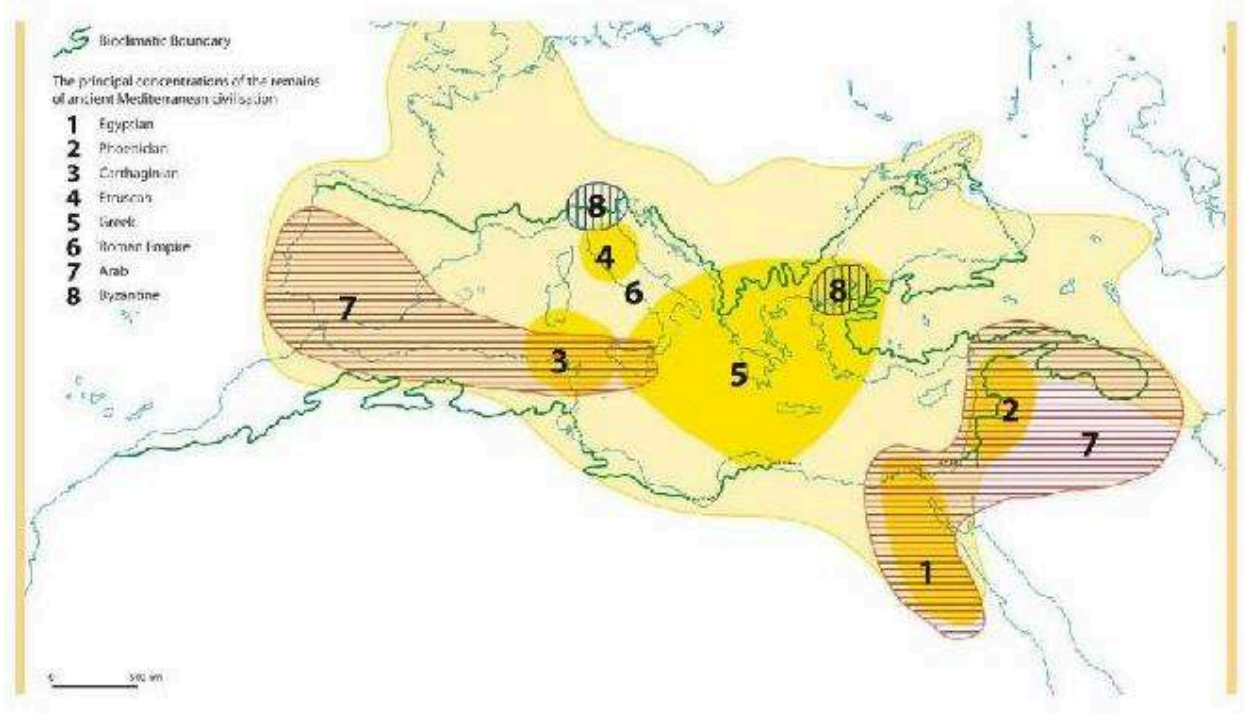

6 Figure 2 shows the regions that have contributed to the development of what we might now call Mediterranean culture. The presence of the Roman Empire is not indicated, having been present throughout the area for many centuries, from the 1st century BC the term Mare Nostrum was used to indicate the region that is today called the Mediterranean Sea.

\section{The Euro-Mediterranean Region: human mobility}

7 Human mobility in the Euro-Mediterranean Region, thus among all EU and non-EU countries looking onto the Mediterranean Sea, saw a rapid growth after World War II, in particular with the growth of tourism, paid holidays for workers, the conclusion of the colonial period, and finally the manpower needs of European countries during postwar reconstruction and new industrial development. According to Eurostat (2021a) the main non-EU Mediterranean countries in terms of foreign-born population residing in 
the EU as at $01 / 01 / 2020$ were Morocco $(2,612,000)$, Turkey $(1,834,000)$, Algeria $(1,397,000)$, Syria $(1,075,000)$, Albania $(478,300)$, Tunisia $(427,000)$, and Iraq $(165,000)$. In total, these communities of citizens from non-EU Mediterranean countries alone make up a network of almost 8 million inhabitants. The countries with the highest concentration of non-EU Mediterranean-born citizens in EU countries are in order France, Germany, Italy and Spain. Figure 3 shows the main migration flows between non-EU and EU countries and countries having the greatest cultural and economic links triggered by migration flows.

Figure 3. EU Member States, 2020. Main groups of foreign-born population by country of birth.

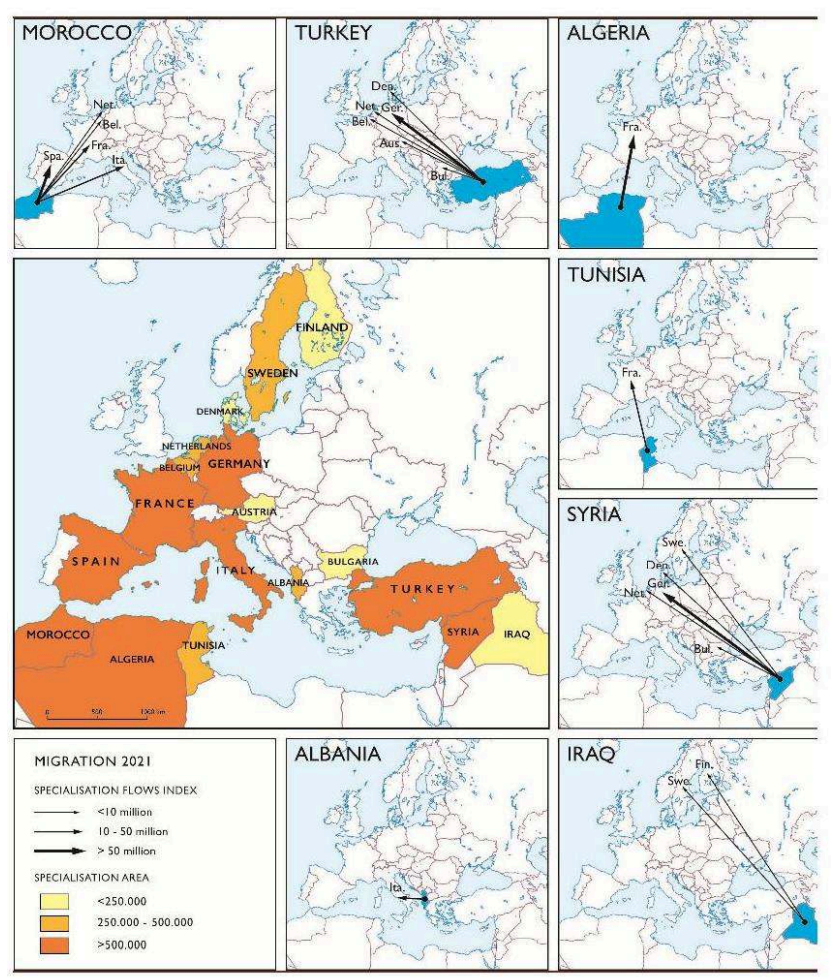

Data source: Eurostat (2021a)

8 According to the UNWTO (2015), a total of 306 million international tourists visited Mediterranean countries, of whom 241 million in EU countries and Israel, 65 million in emerging economy countries and 35 million in the countries of North Africa and the Middle East (MENA). Between 1995 and 2014 countries in North Africa and the MENA region suffered recurring geopolitical crises and the consequences of the so-called Arab Spring of 2011. An emblematic case in point is Egypt, where international tourism grew at an intense pace until 2011, when economic and social events led to extremely volatile flows. 
Figure 4. EU Member States and non-EU Mediterranean countries, 2019. Main destination countries for outbound tourism (nights).

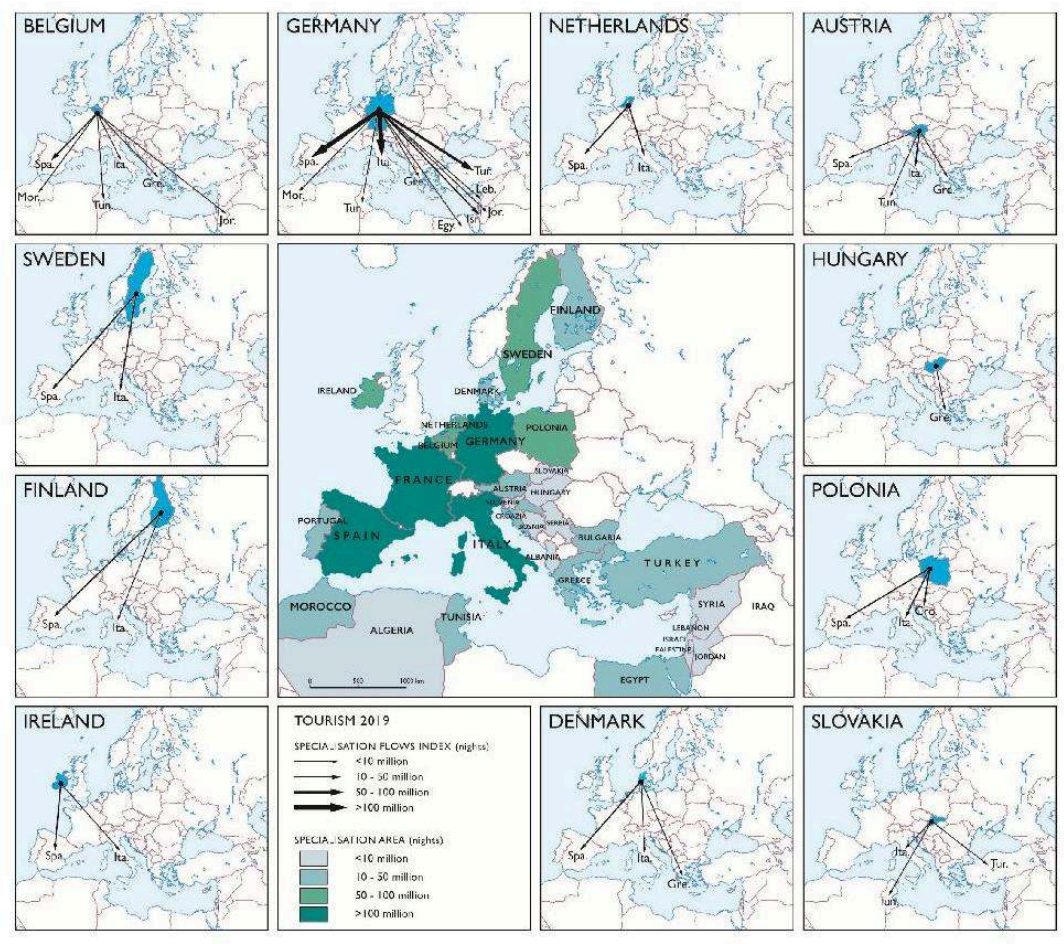

Data source: UNWTO (2015), Eurostat (2021b)

Based on nights spent for outbound destination trips of EU countries, Figure 4 shows the main North-South tourism flows (UNWTO, 2015; Eurostat, 2021b). The main flows starting in non-Mediterranean EU countries come from Germany (451 million nights), the Netherlands (59 million), Austria ( 38 million) and Belgium ( 35 million). The main destination countries for tourism flows originating from EU countries are Spain and Italy, with France playing the dual role of continental and Mediterranean European country. Countries on the southern shores of the Mediterranean have also benefited from these tourist flows, with a good number of tourists from continental Europe being migrants returning home for the holiday period, and therefore fall into the VFR (Visiting Friends and Relatives) category. This, however, is consumer-related mobility, and does not help us to understand the trends and success of international tourism. Then there is the RT (Retirement Migration) category, retirees who decide to spend their retirement years in countries in the northern Mediterranean region. As these moves are for months, or years, this flow of consumption-related mobility is calculated as a form of migration. These figures corroborate at least two trends. There is considerable human mobility in the Euro-Mediterranean area, with overlapping and confusing flows that give a good idea of the fluidity of the processes involved. A previous work (Montanari, Cortese, 1993) presented the demographic trends of countries in the southern Mediterranean in order to estimate the migratory flows that might develop between Africa and Europe. In terms of illegal migration, the Mediterranean might have become similar to what had long been the situation along the Rio Grande, the border between Latin America and the USA. Demographic flows over the past forty years have confirmed the existence of a de facto Euro- 
Mediterranean region based on the mobility of people, information, culture, trade and financial transactions.

\section{Euro-Mediterranean cooperation: help with development, environmental management and human mobility}

The process of implementing development cooperation in the Euro-Mediterranean region has already been examined, and the peculiarities of the Mediterranean area and the characteristics and evolution of the concept of human mobility have been independently defined. These elements are in actual fact closely tied up with one another, and are crucial for the changes taking place in the civil society of Mediterranean countries, due in part to the importance they play in the management of the natural and cultural heritage. Figure 5 gives a logical model correlating all the elements considered in relation to the provision of development cooperation instruments.

Figure 5. The creation of the Euro-Mediterranean Region and human mobility referring to the model of social, economic and environmental changes.

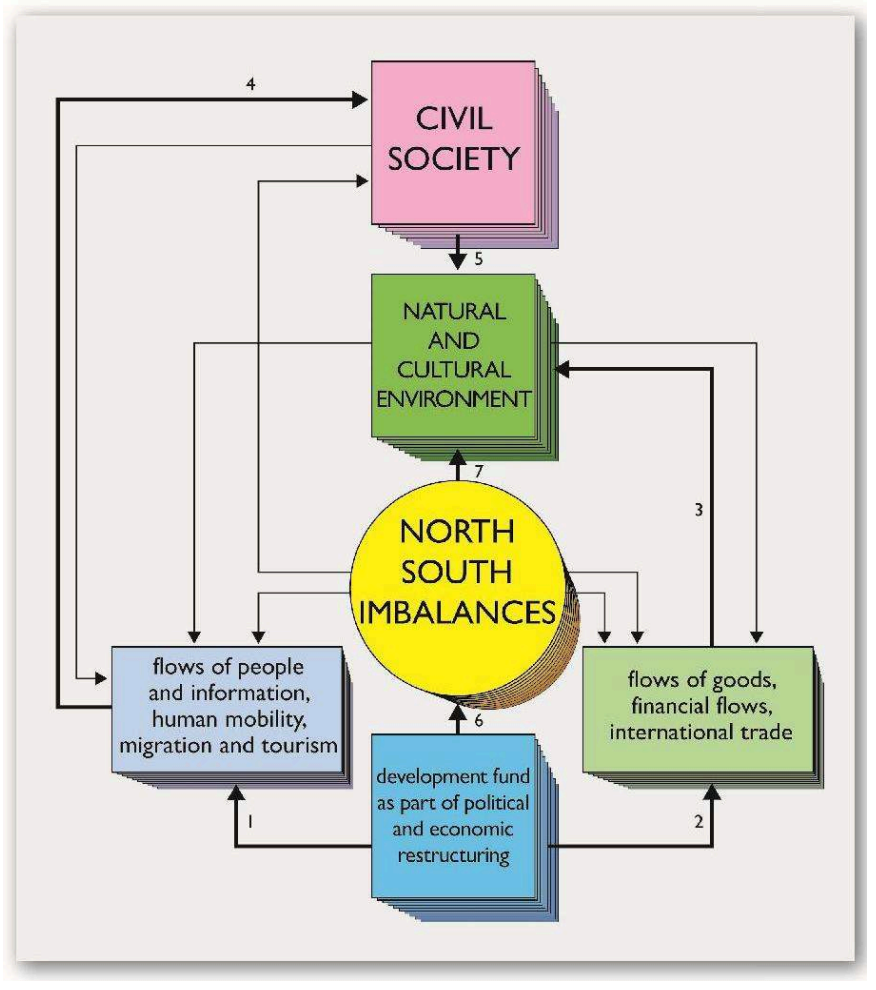

1. Human flows, the construction of a Euro-Mediterranean Partnership allows the orderly management of mass migration, and the migration of skilled labour depending on quantitative and qualitative demand from European markets. Conditions of peace, security and stability will foster: a rise in tourist flows; migration of the elderly and those who have left the labour market (partially or completely); all other types and conditions of geographic mobility;

2. Commodity flows, financial flows and international trade. A greater North-South 
balance can be achieved with a free trade area. Cooperation in production, processing and marketing processes fosters a new vision of the "country of origin" concept;

3. Economic and financial flows referencing the natural and cultural environment. Euro-Mediterranean cooperation has a bearing on the development of productive activities and trade without affecting the consumption of natural and cultural resources, thus complying closely with the principles of sustainable development;

4. Mobility speeds up the processes of transformation in civil society. Cultural globalisation can be balanced out by enhancing specific local features. Orderly and agreed flows promote the meeting of peoples, dialogue and respect among different cultures and religions;

5. Society, the natural and cultural environment. The importing of lifestyles and models has a bearing on the management of those resources that are essential for further development. Civil society can equip itself with the regulatory, economic and cultural instruments that promote the protection of local natural and cultural resources;

6. The North-South Balance. Restructuring actions to promote a lasting economic recovery can more easily attract the confidence and investments of the international community. Reduction in imbalances within the Euro-Mediterranean Region;

7. Development and the natural and cultural heritage. In order to overcome existing imbalances within the Euro-Mediterranean Region, it is necessary to help with the acceleration of economic development, without this being to the detriment of resource consumption.

Starting from the assumptions of the model shown in Figure 5, alternative correlations can be verified based on possible scenarios. The WP "Scenarios Europe 2010. Five possible futures for Europe" drafted at the initiative of the European Consultative Forum on the Environment and Sustainable Development ${ }^{2}$ (EEC, 2001) may be referenced here, providing a purely economic outlook, looking beyond national policies, empowering citizens, enhancing local economies, reducing international instability originating from the situation in the Middle East rather than from countries in the Mediterranean region. 
Figure 6. Human mobility, social and economic changes in the case of a European Union without a Mediterranean policy.

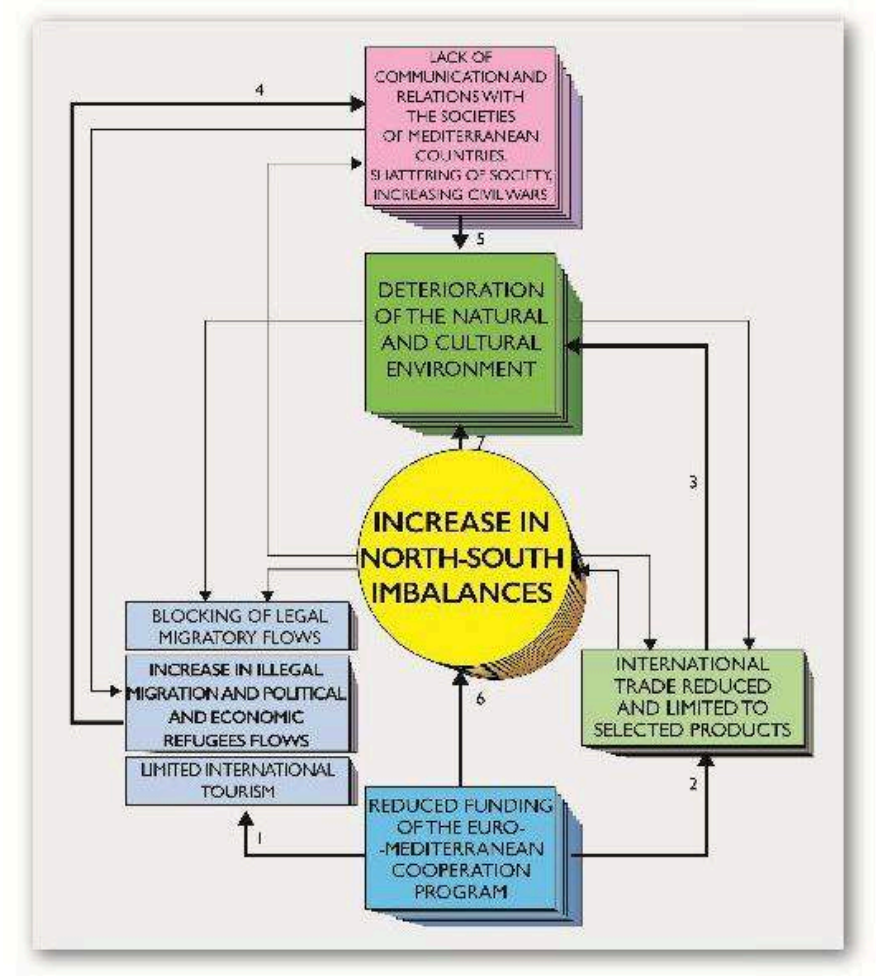

13 Figure 6 shows what will happen if there continues to be no effective European coordination of development policies, and each EU member acts according to its own priorities. In the medium term, this has led to an increase in influence and in bilateral relations, but also to unbalanced growth. This has not encouraged the establishment of a Euro-Mediterranean Region; $1-4$ - 5. Bilateral policies fail in terms of growth of the area or social peace. What they produce above all is uncertainty. They become a hindrance to the flow of tourists, restrict legal migration flows due to the closure of borders, and favour the conditions for the crossing of the Mediterranean on rickety old fishing boats or rubber dinghies, creating illicit turnover worth hundreds of millions of Euros a year, and causing the deaths of thousands of migrants. The failure of migration policies was documented by Agier (2018) who recalled the number of deaths $(40,000)$ in the attempt to cross the Mediterranean. Conditions of social malaise favour the rise of governments that use undemocratic methods, whose main priority is to hold on to power. In this situation it is unlikely that, beyond the formal declarations, sustainable development models will be followed. Without a Euro-Mediterranean collaboration it is unrealistic to think that the countries of the southern shore are capable of achieving efficient sustainable development. The effects of poor management of the environment could spread throughout the Mediterranean, a closed sea where most citizens of EU countries spend their holidays; 2 - 3. Trade is affected by a lack of coordinated policy. This situation favours competitiveness among member States, and allows the trading of products with little added value that do not consider the protection of the natural and cultural assets of countries on the southern shores; 6 - 7. The lack of an efficient EuroMediterranean policy has a direct impact on North-South imbalances, which in turn has an impact on social wellbeing and on the protection of natural and cultural assets. 
The deterioration of these assets in countries in the southern Mediterranean has negative consequences for countries on the northern shores and for the rest of the EU.

Figure 7. The creation of the Euro-Mediterranean Region as part of the balanced management of human mobility in response to foreseeable social, economic and environmental changes.

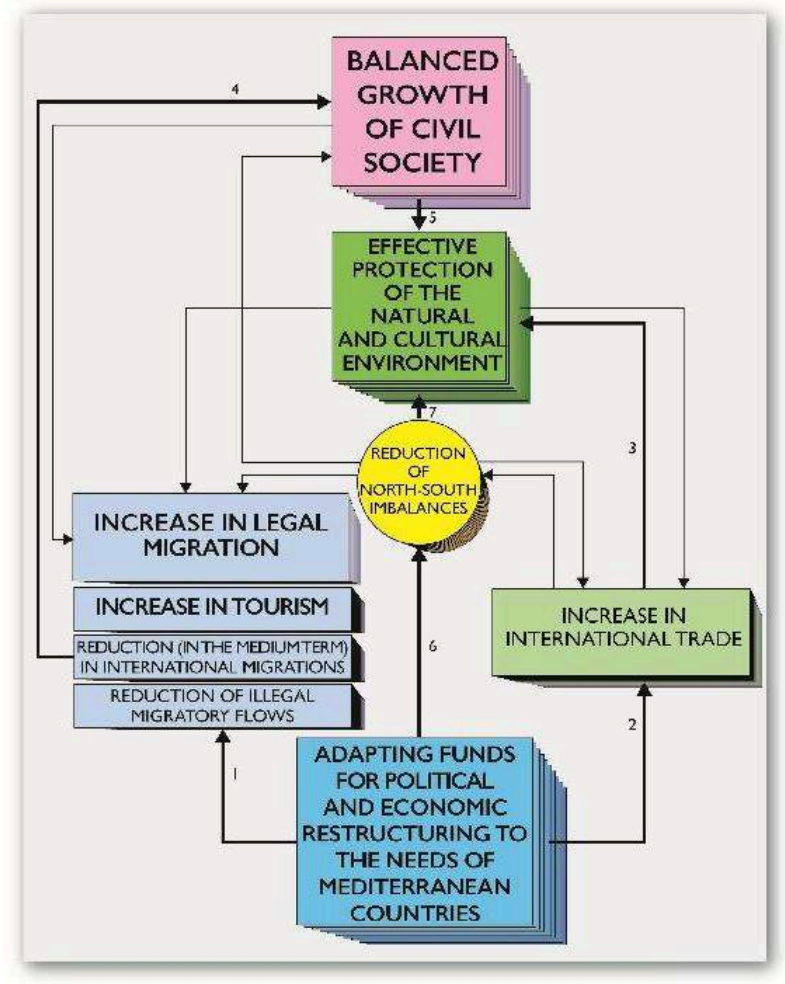

14 Figure 7 considers a model in which all the good intentions and promises of the EU are turned into reality in a reasonably short space of time, making a constant contribution to the balanced growth of societies in the southern Mediterranean. $1-2-3-6-7$. An adequate economic and political investment in a Euro-Mediterranean Union along the lines of the EU model would have significant benefits for the countries in the South, and this in turn would be beneficial for EU countries. It is not a question of grants or donations, therefore, rather investments that would directly impact on reducing the North-South gap, and on the balanced growth of civil society, facilitating the direct management of migration flows in the countries of origin, which would help to significantly reduce illegal migration over time. Balanced North-South cooperation might also help to bring the management of the natural and cultural heritage up to EU standards of protection; 4 - 5. Young, educated people possessing university degrees have migrated from the region, to the detriment of the development of countries in the southern Mediterranean. In most cases these qualifications have not even been recognised by receiving countries, therefore migrants have performed mainly manual labour, resulting in a waste of knowledge. Were there to be greater development and greater democracy at home, young people could stop wishing to move away and make a contribution to the development of their own country. A society that is strengthened by the presence of more culturally evolved social groups is undoubtedly better able to appreciate the positive value of natural and cultural resources for society. The administrations of the EU countries have not yet understood that the Mediterranean is an integral part of their territory, their culture and their economy. The countries of the 
South coast are also an outpost of the problems, difficulties, challenges but also of the great opportunities that the countries of continental Africa will bring to the EU in the coming years.

\section{Covid-19, lockdown and the difficult management of human mobility}

15 The Covid-19 pandemic has been a major obstacle for human mobility. Drastic lockdowns have been imposed in all the countries of the Euro-Mediterranean region. Data and statistics on this topic are lacking for the moment, since the pandemic continues, as of the spring of 2021, to be in full swing. We must necessarily refer therefore to data and trends that need to be substantiated in the long run (Wassler, Fan, 2021). Lockdowns have forced employees to work from home. All international air, rail or road connections have been severed. This has put a sudden stop to the huge thrust of human mobility, be it for work or pleasure. From one day to the next, we went from throngs of people standing in front of city monuments taking selfies to empty streets. National authorities have introduced travel and movement restrictions in an attempt to curb the spread of the pandemic. Airbnb structures are empty. Even those who used to travel to the city centre to work have stayed at home (Montanari, 2020). Hotels, Airbnbs, restaurants, cafes, tourist coaches, taxis and all the other services that had prospered in urban centres have lost custom. In 2020 international tourist numbers fell by $70-80 \%$ in Italy, Spain, Tunisia and Morocco, and by over $90 \%$ in Egypt (Eurostat, 2021b). Even when the lockdown has been eased, the desire for human mobility has not been the same. Restrictions imposed by governments have had a negative impact on the travel industry, but what is most worrying is that uncertainty as to the success of pandemic measures may have had a negative psychological impact on consumers (Myung, Bonn \& Hall, 2021).

16 Equally negative are the figures for those travelling for business reasons or to attend international conferences. All of these activities have now been replaced by online virtual meetings. Experts in the sector ask whether Covid-19 might put an end to the problem of overtourism. This question overlaps with that posed by several public administrations, which seek to understand how long it will take to return to the previous situation, perhaps with a view to comforting entrepreneurs and getting them to see light at the end of the Pandemic tunnel. Although there is a widespread belief that it will be necessary to wait until 2023, or longer, for the economy to recover, there are those who hope better times will come sooner. Europe's tourism industry expects to see some fundamental changes in the sector: 1) health concerns will direct demand towards smaller journeys, in one's region or country; 2) a smaller number of travellers will bring about a rise airline fares, and it may be less advantageous to go on holiday in far-flung countries; 3) airlines will have to reconcile on-board security with profit margins, this may also push up air travel costs; 4) cruise companies that have invested in maxi-liners may have to pursue a downsizing policy. They will have to reduce itineraries, limit the number of passengers on board, check the health of passengers and suspend or reduce buffet services; 5) the hotel sector will prioritise technologies designed to avoid physical contact. New investments will be needed, and each client will require a greater space; 6) tourist attractions will have to be less crowded, and 
activities managed more rigorously, respecting social distancing norms; 7) large events and mass gatherings will have to be limited.

International discussions are ongoing, considering whether we should return quickly to the previous situation, or admit from the outset that the previous model of development, one that has led us to the overtourism of beaches and historic cities, is no longer viable, and that it is necessary to begin to think about alternatives (Yanes Torrad, 2021). If the second hypothesis were to prevail, funding made available to businesses would no longer be used to return to previous levels of tourism and outdated practices, rather it would serve to introduce measures to protect the environment more effectively and to use the possibilities offered by IT in innovative ways. The tourism sector, in Italy and in many other Mediterranean countries, is basically made up of small and very small businesses. To meet their needs, it will be necessary to finance the spread of information and communication technologies and technological innovation, and to reduce the impact of consumption on environmental resources. Training activities will accordingly be needed to promote the advanced use of information and communication technologies. As part of renewed and intensified Euro-Mediterranean cooperation, new conditions will have to be established to manage human mobility within the region. The various forms of migration can be better prepared, agreed upon and managed in order to increase legal migration and reduce illegal migration. At a macro level tourism is suffering from the imbalance of forms of overtourism in cities and along European coasts while non-European countries are suffering from undertourism. In a less uncertain situation, the provision of adequate infrastructures and services may in the future reduce excessive tourist pressure in the North and redistribute some of it to the South.

\section{Conclusions}

It is clear from the lack of results achieved over a few decades that the creation of a Euro-Mediterranean Union has not been one of the EU's priorities. Global events and local situations have given some EU member states reason to put off those initiatives and avoid policies that should have been implemented in a short space of time. The Mediterranean countries of the EU have not had the will or the strength to place the problems of the Mediterranean at the core of the political agenda. Non-Mediterranean EU countries have not appreciated the fact that what happens in the Mediterranean region has an effect on the quality of their environment, territory, society and economy. Relations between EU countries and African countries pass through the Mediterranean. This essay puts the spotlight on a number of factors needed to create a situation of mutual convenience between the countries of the North and those of the South. Cooperation is difficult despite the evident mutual benefits. The establishment of a Euro-Mediterranean area, about which much has been said, and which can no longer be put off, remains a complex process. We are now experiencing an emergency caused by the consequences of the Covid-19 pandemic. It appears clear that when this emergency is over we should not permit a return to the previous situation. Major crises require major changes, therefore recovery plans should be based on the idea that nothing should return to the way it used to be. This idea is valid too for the realisation of effective Euro-Mediterranean cooperation. Today, such collaboration appears to be the only effective tool for redistributing excess tourism from the North to the South 
and for managing illegal migration flows. For this cooperation to be realised, a EuroMediterranean Union needs to be established, based on the same principles and foundations as the EU.

\section{BIBLIOGRAPHY}

AGIER M. (2018), L'étranger qui vient. Repenser l'hospitalité, Paris, Éditions du Seuil.

BORRELL J. (High Representative of the EU for Foreign Affairs and Security Policy) (2021), A new start for the Mediterranean, from the blog on 02/03/2021, https://eeas.europa.eu/diplomaticnetwork/union-mediterranean-ufm/946

CEBECI M., SCHUMAKER T. (2017), The EU's construction of the Mediterranean (2003-2017), MEDRESET Working Paper No. 3 (April).

CEE (2001), Activity and self-assessment report 1997-2001, Scenario Europe 2010. Five possible futures for Europe, Luxembourg, Office for Official Publications of the European Communities, http:// europa.eu.int/comm/cdp/index_en.htm

EUROPEAN COMMISSION (2021), Southern Neighbourhood: EU proposes new Agenda for the Mediterranean, Press release 09/02/2021, https://ec.europa.eu/commission/presscorner/detail/ en/ip_21_426

EUROSTAT (2021a), Migration and migration population statistics, Eurostat, Luxembourg.

EUROSTAT (2021b), Tourism, https://ec.europa.eu/eurostat/web/tourism/data/database

HALL C.M., WILLAMS A.M. (eds.) (2002), Tourism and Migration. New Relationship between Production and Consumption, Dordrecht, Kluwer.

ISAAC S.K., KARES H.E. (2017), The European Community framing of the Mediterranean (1970-1990), MEDRESET Working Paper No. 1 (April).

TSOUKALIS L. (1977), “The EEC and the Mediterranean: Is “Global’ Policy a Misnomer?”, International Affairs, 53, 3, pp. 422-438, https://doi.org/10.2307/2615313

MACRON E. (2020), Déclaration de M. Emmanuel Macron, président de la République, sur le Sommet des pays du sud de l'Union européenne, Ajaccio, 10/09/2020, https://www.vie-publique.fr/discours/ 276209-emmanuel-macron-10092020-france-pays-mediterraneens

MARCHENA GÓMEZ M.J., VERA REBOLLO F. (1995), “Coastal areas: processes, typologies and prospects”, in MONTANARI A., WILLIAMS A.M., European Tourism. Regions, spaces and restructuring, Chichester, Wiley, pp. 111-126.

MONTANARI A. (1998), "Flows of goods and people in the Euromediterranean region", in CONTI S., SEGRE A. (eds.), Mediterranean geographies, Geo-Italy 3, Società Geografica Italiana, Roma, pp. 159-170.

MONTANARI A. (2005), "Human mobility, global change and local development", Belgeo, 1-2, pp. 7-18. 
MONTANARI A. (2006), « Le bassin méditerranéen. La mobilité humaine pour la réalisation d'une macrorégion ", in DECROLY J.M., NICOLAÏ H. (dir.), Mutations des territoires dans le Monde à l'aube du XXI ${ }^{e}$ siècle, L'Harmattan, Paris, pp. 79-105.

MONTANARI A. (2020), "Covid-19 as an opportunity to tackle the phenomenon of overtourism in European historic centres: the case of Rome", Il Capitale Culturale, 11, pp. 285-305.

MONTANARI A., CORTESE A. (1993), "South to North migration in a Mediterranean perspective”, in KING R. (ed.), Mass migrations in Europe: the legacy and the future, Belhaven Press, London and New York, pp. 212-231.

MONTANARI A., MAGNARAPA C. (1998), “The geography of marine tourism and recreation”, in AAVV, Italy's Sea, problems and perspectives, Roma, Società Geografica Italiana, pp.167-187.

MORILLAS P., SOLER I LECHA E. (2017), The EU's framing of the Mediterranean (1990-2002): Building a Euro-Mediterranean partnership, MEDRESET Working Paper No. 2 (April).

MYUNG J.K., BONN M.A. \& HALL C.M. (2021), “What influences Covid-19 biosecurity behaviour for tourism", Current issues in tourism, pp. 1-7.

PRODI R. (Presidente della Commissione Europea) (2004), Discorso tenuto a Genova, gennaio, https://ec.europa.eu/commission/presscorner/detail/it/SPEECH_04_6

SARKOZY N. (2007), Déclaration de M. Nicolas Sarkozy, ministre de l'intérieur et de l'aménagement du territoire, président de l'UMP et candidat à l'élection présidentielle, sur son souhait de voir se réunifier l'espace méditerranéen pour le remettre au cour de la civilisation occidentale et de la mondialisation, Toulon (Var), 7 février, http://discours.vie-publique.fr/notices/073000533.html

TOMÁS SALVÁ P.A. (2002) “The complex human mobility flows in the Mediterranean Region: the case of the Balearic Islands as phenomenon type <New California>", in MONTANARI A. (ed.), Human Mobility in a borderless world?, Roma, SGI, pp. 243-258.

UNION FOR THE MEDITERRANEAN (2017), Mission, http://ufmsecretariat.org/?p=2

WASSLER P., FAN D.X.F. (2021), “A tale of four futures: tourism, academia, and Covid-19”, Tourism Management Perspectives, pp.1-30.

YANES TORRAD S. (ed.), La cuestions turistica. Trece entervistas para repensar el turismo, Barcelona, Pasos.

UNWTO (2015), Tourism in the Mediterranean, 2015 Edition, UNWTO, Madrid, https://www.eunwto.org/doi/pdf/10.18111/9789284416929

\section{NOTES}

1. The GLOBILITY (Global Change and Human Mobility) research network was founded in 2000 as part of IGU (International Geographical Union) activities. An initial phase (2000-2012) was coordinated by A. Montanari and Y. Ishikawa, the second phase has been coordinated since 2012 by J. Dominguez Mujica and B.Staniscia https://www.globility.org/

2. A. Montanari was a member (1993-2000) and vice-president (1998-2000) of the European Consultative Forum. 


\section{ABSTRACTS}

The Euro-Mediterranean region represents an area of possible collaboration, but also of possible conflict, between EU nations and countries in the Mediterranean region that are not EU members. The reasons for effective cooperation have been evident for decades, and may be summarised as follows: increased trading and economic assistance in exchange for lasting peace. Over the years we have also begun to realise that the environment and cultural heritage of the Mediterranean need to be protected, also in the interest of EU countries with no direct access to the Mediterranean Sea. Covid-19 and the measures introduced to combat it are changing many of the ways our societies work. Human mobility, for example, in the form of migrant and tourist flows, is being transformed from a global phenomenon to a proximity relationship. The concept of proximity is still being defined. The Mediterranean may well be considered, in the near future, as an area of enhanced accessibility for all EU countries.

La région euro-méditerranéenne représente une source d'éventuelles collaborations et également de conflits potentiels entre les pays de l'UE et ceux faisant partie de la région mais non membres de l'UE. Depuis plusieurs dizaines d'années déjà, les raisons motivant une collaboration efficace se sont surtout centrées sur la facilitation des échanges commerciaux et l'aide économique en contrepartie d'une paix durable. Les années passées ont permis de mettre en évidence que l'environnement et le patrimoine culturel méditerranéens devaient être protégés également dans l'intérêt des pays UE n'ayant pas d'ouverture directe sur la Méditerranée. La Covid-19 et les mesures introduites pour lutter contre la pandémie transforment les habitudes de nos sociétés. Par exemple, la mobilité des personnes, formée par des flux migratoires et touristiques, évolue actuellement, passant d'un phénomène global à une relation de proximité. Le concept de proximité est encore en phase de définition et il n'est pas à exclure que la Méditerranée, dans un avenir proche, soit considérée comme une zone offrant une meilleure accessibilité à l'ensemble des pays de l'UE.

\section{INDEX}

Keywords: Euro-Mediterranean Region, human mobility, development, environmental management, Covid-19

Mots-clés: région euro-méditerranéenne, mobilité des personnes, développement, gestion de l'environnement, Covid-19

\section{AUTHOR}

\section{ARMANDO MONTANARI}

A. Montanari has held posts of professor of tourism geography and human mobility and President at the Sapienza University of Rome, School of Tourism, before taking up the position of deputy President at the Sara Envimob Srl Sapienza University innovative startup. He has been the author of about tree hundreds scientific articles and volumes in Italian, English, French, Spanish and Japanese and coordinator of numerous international research projects since 1979 (https://www.researchgate.net/profile/Armando_Montanari) 